\title{
CLIMATE CHANGE AND VITICULTURE IN TÎRGU MUREȘ
}

\author{
Ottilia RUSZ ${ }^{1}$
}

\section{DOI: 10.24193/AWC2020_22}

\begin{abstract}
Climate conditions are important for viticulture. For instance, in the period of "Medieval Climatic Optimum" (900-1300) northern boundary of viticulture reached the Baltic, while the so-called „Little Ice Age” (1300-1850) affected grape production in Europe and viticulture pulled up to Southern Europe. The last decade's warming is beneficial for viticulture in many regions, e.g. we deal longer and warming growing season. Climate change does not mean only positive effect on viticulture, may induce some negative effects, e.g. increasing of extreme events. Tîrgu Mureș is not known for viticulture. However, climate change may induce some favorable conditions in that direction. The signs of climate change in Tîrgu Mureş are: warming trend; actually, no change in precipitation or in frequency of extreme events. In the last 30 years (1988-2017) mean annual temperature reached $9.5^{\circ} \mathrm{C}$. In the 1951 1981 period this value was $8.8^{\circ} \mathrm{C}$ (while the minimum threshold for viticulture is $9.0{ }^{\circ} \mathrm{C}$ ). After Pálfai Drought Index, no extreme, very serious, serious or heavy drought was registered, only a moderate drought was recorded in 1987. There are many indices for viticulture. An increasing, statistical significant trend is characteristic for many temperature indices. There is no statistical significant trend regarding the precipitation indices. Based on Huglin index (HI), Tîrgu Mureș may be included in the second class (cool), and based on Winkler index (WI) may be included in the first region (very cool). Sen's slope estimate for these two indices are 5.417 (for HI) respectively 4.300 (for WI). If the trend of Winkler index will remain the same, as in the next 1-2 decades, this index will reach 1390 (region II.: cool). The decreasing, statistical significant trend of FS15D (Vitis Serious Frost Risk Days) may have also a positive effect on viticulture in Tîrgu Mureș.
\end{abstract}

Keywords: viticulture, climate change, Tîrgu Mureș, Huglin index, Winkler index

\section{INTRODUCTION}

Viticulture is strongly influenced by climate, especially by temperature, precipitation and solar radiation. Some favorable climatic conditions are:

- $\quad$ Mean annual temperature: $9-21{ }^{\circ} \mathrm{C}$

\footnotetext{
${ }^{1}$ Meteorological Quality Service Târgu Mureş, Romania, e-mail: ruszotti@yahoo.com
} 
- Mean annual precipitation amount: 500-600 $\mathrm{mm}$ (also rainfall distribution is important)

- Mean temperature of ripening period: $19-20{ }^{\circ} \mathrm{C}$

- Resistance to low temperature in winter of trunks: $-18 /-20^{\circ} \mathrm{C}$

- Minimum active heat sum: $850^{\circ} \mathrm{C}$

- Minimum sunshine hours in the period April-September: 1200 hours (Bognár and Mercz, 1995, Berbecel and Stancu, 1970, Csete and Nyéki, 2006).

Climate conditions are important for viticulture In the period of "Medieval Climatic Optimum" (900-1300) northern boundary of viticulture reached the Baltic and southern England, while the so-called „Little Ice Age” (1300-1850) affected grape production in Europe and viticulture pulled up to Southern Europe (Jones, 2007).

The last decades warming is beneficial for viticulture in many region (longer and warming growing season). For example, from 2004 to 2013, the vineyard area in the United Kingdom (UK) increased 148\%. (Nesbitt et al., 2016). Climate change does not mean only positive effect on viticulture, may induce some negative effects, e.g. increasing of extreme events. Short-term and long-term adaptation strategies are needed. (Fraga et al., 2013).

In Romania, there are eight wine regions (Irimia et al., 2017). Tîrgu Mureș is located in the center of Transylvania (Romania). The Transylvania Plateau wine region are:

- Vineyard Târnave (Blaj, Jidvei, Mediaș, Târnăveni, Zagăr, Valea Nirajului)

- Vineyard Alba (Alba Iulia, Ighiu)

- Vineyard Sebeș-Apold (Sebeș, Apold)

- Vineyard Aiud (Aiud, Turda, Triteni)

- Vineyard Lechința (Lechința, Teaca, Bistrița, Batoș)

There are some ecoclimate data of Transylvania Plateau wine region:

- $\quad$ Altitude: $175-544 \mathrm{~m}$

- Mean annual precipitation amounts: 535-689 mm

- Sunshine hours: 1284-1391 hours

- Mean temperature of July: $18.9-20.5^{\circ} \mathrm{C}$

- Maximum temperature of August: $37.5-42.5^{\circ} \mathrm{C}$

- Number of days with maximum temperature $>30^{\circ} \mathrm{C}$

(Agrometeorological training course, internal material NMA, 2004)

Tîrgu Mureș is not known for viticulture. However, climate change (especially warming tendencies) may induce some favorable conditions in that direction.

In the end of 19th many time it's mentioned Apor Károly's name in Borászati Lapok (a periodical intended for viticulture and wine production), who had a vineyard near Tîrgu Mureș (in Tofalău) and produced excellent wine (articles from Borászati Lapok, 1888, 1896).

It should be mentioned, that the soil and the topography also is significant in viticulture, moreover the local and microclimate conditions. 


\section{SOME CLIMATIC CHARACTERISTICS OF TÎRGU MUREŞ}

Climate data from Tîrgu Mureș meteorological station (elevation $308 \mathrm{~m}$ ) were used, from the period 1951-2017. Tabel 1 present some general multiannual data regarding temperatures, precipitation amounts and sunshine hours.

Table 1. Some annual climate data in Tîrgu Mureș

\begin{tabular}{|c|c|c|}
\hline Mean annual temperature & $1951-2017$ & $9.1^{\circ} \mathrm{C}$ \\
\hline Absolute maximum temperature & $1951-2017$ & $38.8^{\circ} \mathrm{C}(08.2012)$ \\
\hline Absolute minimum temperature & $1951-2017$ & $-32.8^{\circ} \mathrm{C}(01.1963)$ \\
\hline Precipitation amount & $1951-2017$ & $586.4 \mathrm{~mm}$ \\
\hline Sunshine hours & $1961-2017$ & 1979 hours \\
\hline
\end{tabular}

Monthly data (temperatures, precipitation amounts) are shown in fig. 1-3.
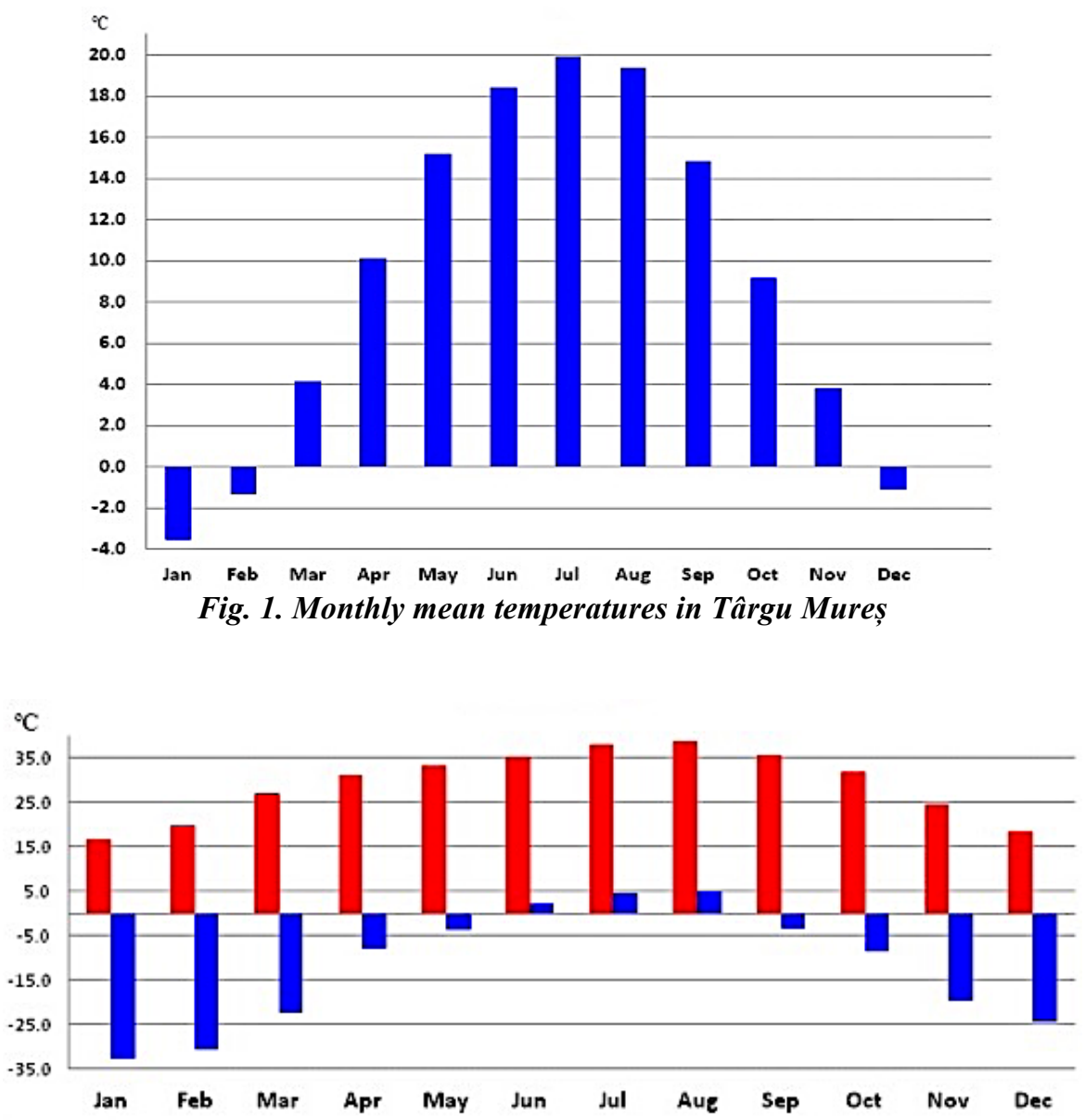

Fig. 2. Absolute monthly maximum (red) and minimum (blue) temperatures in Târgu Mureș 


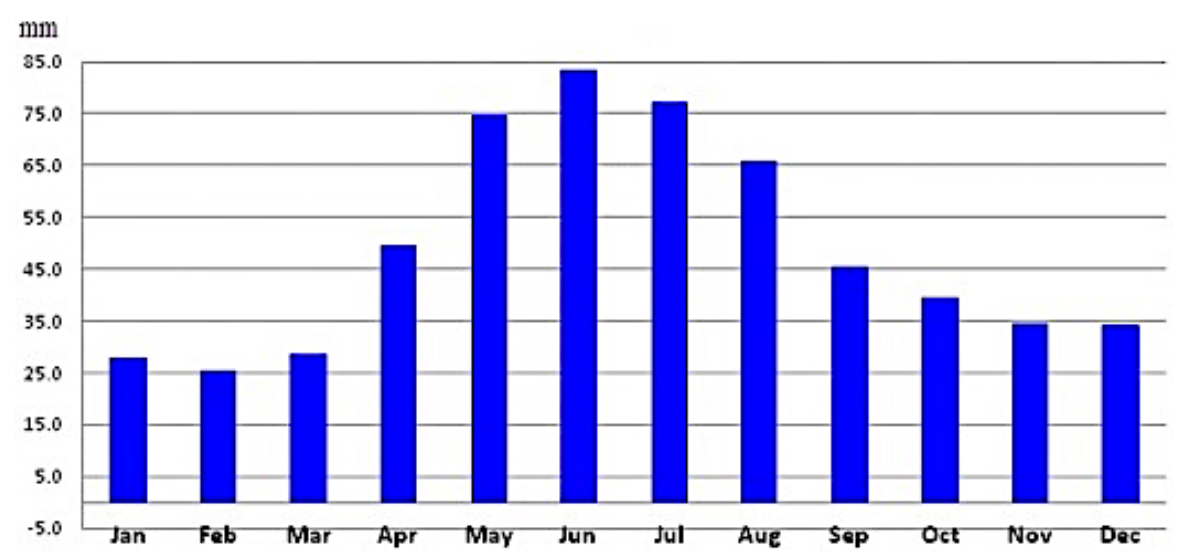

Fig. 3. Monthly precipitations amount in Târgu Mureș

Also, some dangerous meteorological phenomena for grape were studied. Mean number of days of hoar frost/year are 46. The first day of appearance of this meteorological phenomena is 5 October, the last day is 22 April. Mean number of days of glaze/year are 2, and may appear between November and February. The hail is present in average one time/year, between March-September.

Number of days covered by snow are 60. The first day of (not durable) snow cover is 18 November, the last day is 11 March. Snow depth is highest in January: 7 $\mathrm{cm}$, in February $6 \mathrm{~cm}$, while in December $3 \mathrm{~cm}$. All these are average values.

Temperature inversions appear when temperature increases with altitude. This is a relatively frequent phenomenon in Transylvania, and may be important for viticulture. The Târnăveni meteorological station is located at $523 \mathrm{~m}$ elevation, and often has a behavior as a mountain in terms of temperature inversions. While Târnăveni town is under $300 \mathrm{~m}$ elevation. That can explain why there are often higher minimum temperatures in winter compared to nearly station, Târgu Mureş $(308 \mathrm{~m}$ ) or why here number of tropical days are greatest. Since 1987 (when it was founded) at Târnăveni meteorological station the minimum temperatura never was under $-20^{\circ} \mathrm{C}$ (Rusz, 2015).

In 2018, a second automated weather station was installed in Târgu Mureş at elevation $465 \mathrm{~m}$ (Cornești Plateau). For example, the mean of minimum temperatures of March in 2019 there was $+2.0^{\circ} \mathrm{C}$, while in the main meteorological station $(308 \mathrm{~m})-0.6^{\circ} \mathrm{C}$.

\section{CHANGE IN CLIMATE TIME SERIES FROM TÎRGU MUREȘ}

Mann-Kendall trend analysis (Mann, 1945; Kendall, 1975) was applied in order to analyze the linear trend, and Sen's slope estimate (Sen, 1968) was calculated to determine the rate of the trends, using Makesens software (Salmi et al., 2002). 
Positive, statistically significant trends are in case of the mean annual temperature, mean summer temperature and yearly sunshine hours (Table 2.)

Table 2. Linear trend of mean annual, mean summer, mean winter temperature and yearly sunshine hours

\begin{tabular}{|l|l|}
\hline \multicolumn{2}{|c|}{ Mann-Kendall trend, Sen's slope estimate. } \\
\hline \multicolumn{2}{|c|}{ Significant values are shown in bold (at confidence level $* * *=\mathbf{0 . 0 0 1})$} \\
\hline Mean annual temperature (1951-2017) & $\mathbf{0 . 0 2 1} * * *$ \\
\hline Mean summer temperature (1951-2017) & $\mathbf{0 . 0 3 2} * * *$ \\
\hline Mean winter temperature (1951-2017) & 0.015 \\
\hline Sunshine hours (1961-2017) & $\mathbf{4 . 7 1 0} * * *$ \\
\hline
\end{tabular}

Not only the linear regression line, but also the $6^{\text {th }}$ order polynomial regression line shown that in case of mean annual temperature there is a clearly warmer trend (Fig. 4).

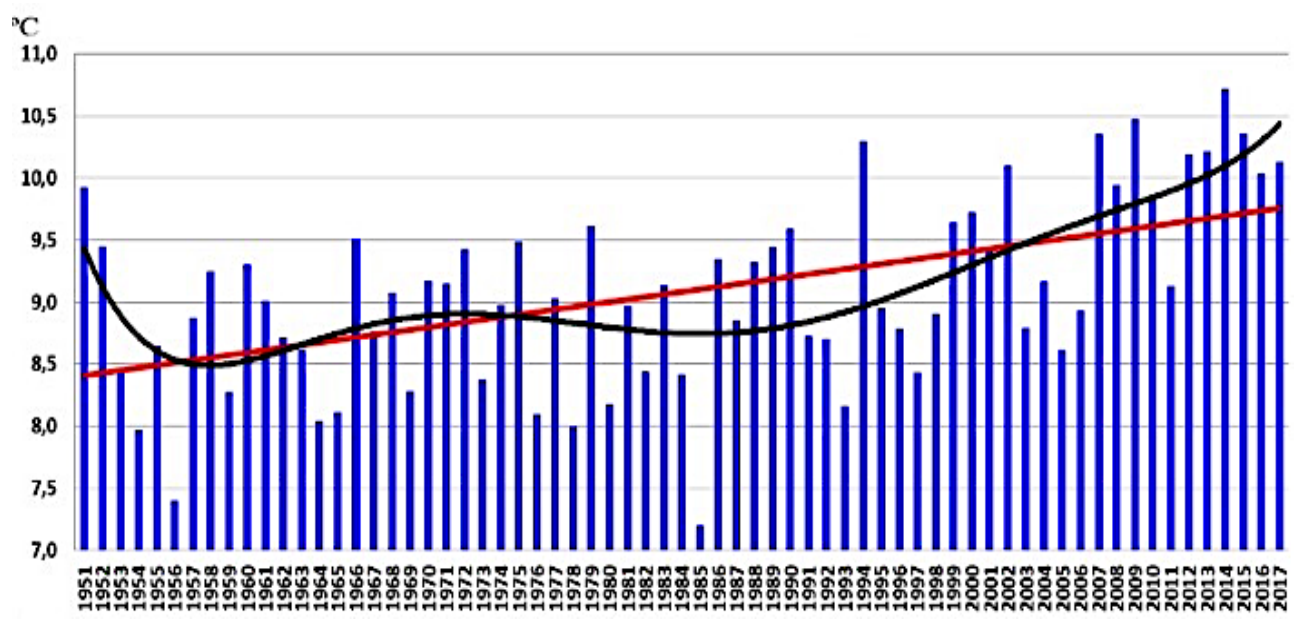

Fig. 4. Linear (red) and $6^{\text {th }}$ order polynomial (black) regression line of mean annual temperature

Overlapped mean annual and summer mean temperatures reveals that higher values of temperatures are in the last decades. However, there are no significant trends of winter temperatures, overlapped time periods shown, that in the last decades we are deal with higher values. (Fig. 5-7).

In case of precipitation, generally there are no statistically significant trends (Table 3). No extreme, very serious, serious or heavy drought was registered. A moderate drought was in 1987 (Pálfai Drought Index) (Rusz, 2019). 


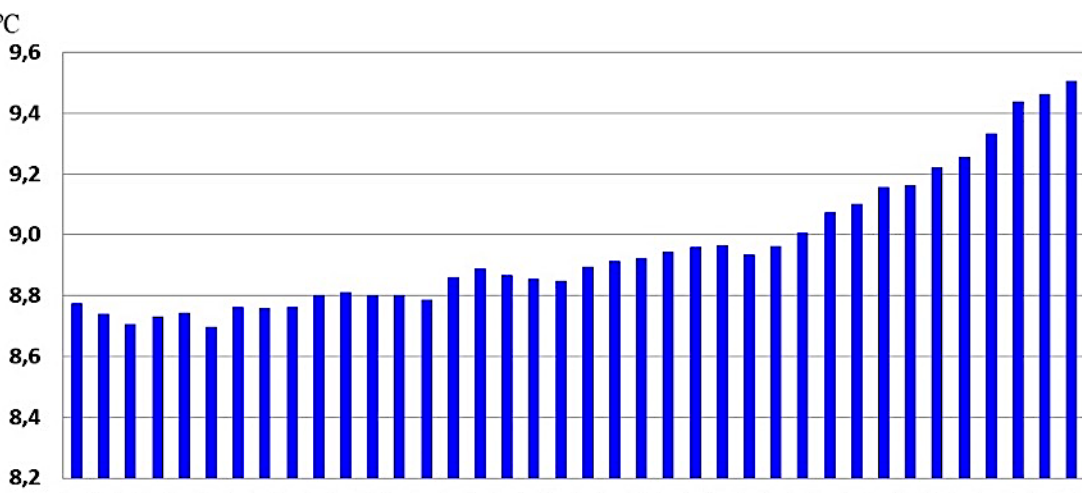

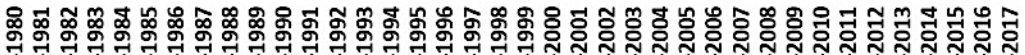

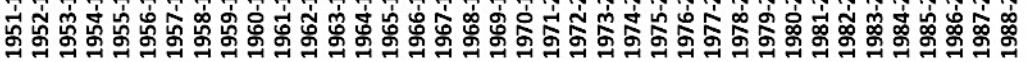

Fig. 5. Mean annual temperatures, 30 years overlapped periods

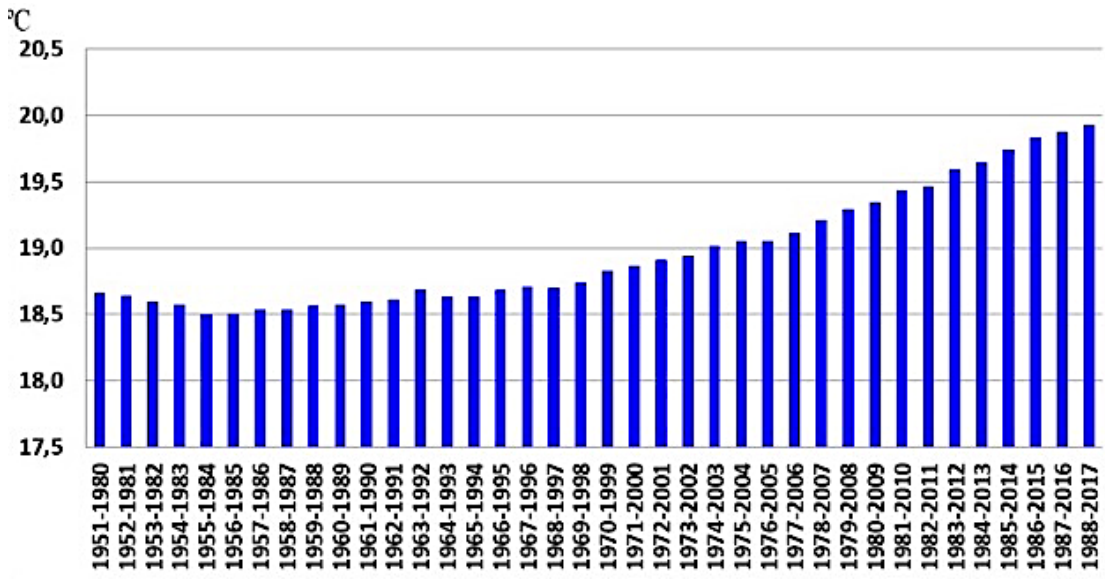

Fig. 6. Mean summer temperatures, 30 years overlapped periods

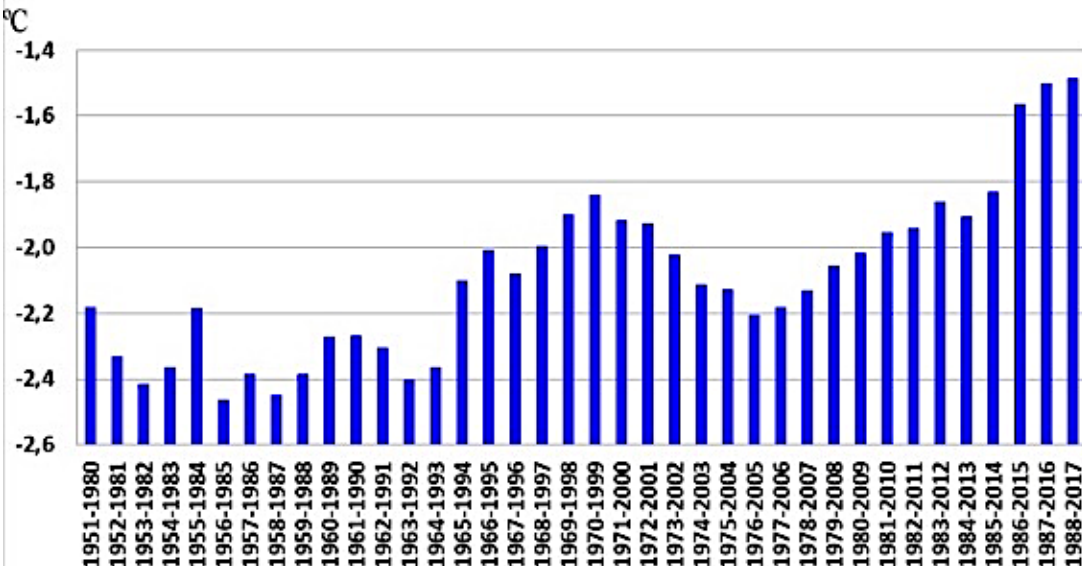

Fig. 7. Mean winter temperatures, 30 years overlapped periods 
Table. 3. Linear trend of number of days with: liquid and solid precipitation, maximum amount of precipitation/24 hours, and precipitations amount over thersholds sets

\begin{tabular}{|l|l|l|l|l|l|l|l|l|l|l|}
\hline $\begin{array}{l}\text { Number } \\
\text { of days } \\
\text { with } \\
\text { precipita } \\
\text { tion: }\end{array}$ & Max/24h & liquid & solid & $0.1 \mathrm{~mm}$ & $0.5 \mathrm{~mm}$ & $1.0 \mathrm{~mm}$ & $2.0 \mathrm{~mm}$ & $5.0 \mathrm{~mm}$ & $10.0 \mathrm{~mm} 20.0 \mathrm{~mm}$ \\
\hline $\begin{array}{l}\text { Linear } \\
\text { trend }\end{array}$ & -0.010 & 0.194 & -0.139 & 0.100 & 0.000 & 0.055 & 0.027 & 0.063 & 0.038 & 0.000 \\
\hline
\end{tabular}

\section{CLIMATE INDICES FOR VITICULTURE AND TRENDS}

Temperature indices, rainfall indices and extreme indices and the standard deviations (Hlaszny, 2012) were calculated using climate data from Târgu Mureş meteorological station, period 1951-2017. Also, linear trends were studied, using Mann-Kendall test (Mann, 1945; Kendall, 1975), Sen's slope estimate (Sen, 1968) and Makesens soft (Salmi et al., 2002). The result is presented in Tabel 4-6.

Table 4. Temperature indices for viticulture in Târgu Mureş (period 1951-2017) Significant values are shown in bold (at confidence levels: $* * *=0.001, * *=0.01, *=0.05,+=0.10$ )

\begin{tabular}{|c|c|c|c|c|}
\hline Temperature Index & & Mean & $\begin{array}{c}\text { Standard } \\
\text { Deviation }\end{array}$ & $\begin{array}{c}\text { Linear trend (Mann- } \\
\text { Kendall test, Sen's }\end{array}$ \\
\hline Huglin-index & HI & 1606,96 & 179,31 & $\mathbf{5 . 4 1 7} * * *$ \\
\hline Winkler-index & WI & 1246,94 & 147,40 & $\mathbf{4 . 3 0 0} * * *$ \\
\hline $\begin{array}{c}\text { Biologically Effective Day } \\
\text { Degrees }\end{array}$ & BEDD & 1111,11 & 91,15 & $\mathbf{2 . 3 7 0} * * *$ \\
\hline $\begin{array}{c}\text { Mean July Temperature } \\
\text { Mean january temperature }\end{array}$ & MjuT & 19,9 & 1,43 & $\mathbf{0 . 0 3 3} * * *$ \\
\hline $\begin{array}{c}\text { Growing Season Average } \\
\text { Temperature }\end{array}$ & GSAT & $\mathbf{- 3 , 5}$ & 2,93 & 0,024 \\
\hline $\begin{array}{c}\text { Growing Season Average } \\
\text { Maximum Temperature }\end{array}$ & GSATX & $\mathbf{2 2 , 2}$ & 1,13 & $\mathbf{0 . 0 2 3} * * *$ \\
\hline $\begin{array}{c}\text { Growing Season Average } \\
\text { Minimum Temperature }\end{array}$ & GSATN & $\mathbf{9 , 4}$ & 0,61 & $\mathbf{0 . 0 3 0} * * *$ \\
\hline $\begin{array}{c}\text { Harvest Maximum } \\
\text { Temperature }\end{array}$ & HMX & $\mathbf{2 5 , 2}$ & 1,40 & $\mathbf{0 . 0 1 7} * * *$ \\
\hline $\begin{array}{c}\text { Winter Minimum } \\
\text { Temperature }\end{array}$ & WMN & $\mathbf{- 3 2 , 8}$ & 4,69 & $0,045 * * *$ \\
\hline $\begin{array}{c}\text { Ripening Average } \\
\text { Temperature }\end{array}$ & RAT & $\mathbf{1 4 , 9}$ & 0,97 & $\mathbf{0 . 0 1 5 *}$ \\
\hline $\begin{array}{c}\text { Cool Night Index } \\
\text { Continentality }\end{array}$ & CNI & $\mathbf{9 , 0}$ & 1,26 & 0,012 \\
\hline $\begin{array}{c}\text { CO } \\
\text { Ges, }\end{array}$ & $\mathbf{2 3 , 5}$ & 0,007 \\
\hline
\end{tabular}


Table 5. Rainfall indices for viticulture in Târgu Mureş (period 1951-2017) There are no significant trends

\begin{tabular}{|c|c|c|c|c|}
\hline Rainfall Index & & Mean & $\begin{array}{c}\text { Standard } \\
\text { Deviation }\end{array}$ & $\begin{array}{c}\text { Linear trend } \\
\text { (Mann-Kendall } \\
\text { test, Sen's slope } \\
\text { estimate) }\end{array}$ \\
\hline Annual rainfall & AR & 586,4 & 103,43 & 0,466 \\
\hline Summer rainfall & SR & 160,7 & 55,86 & 0,152 \\
\hline Winter Precipitation & WR & 151,1 & 39,54 & $-0,161$ \\
\hline Growing Season Precipitation & GSR & 435,6 & 92,19 & 0,448 \\
\hline Bloom Period Precipitation & BPR & 81,7 & 33,02 & 0,276 \\
\hline Ripening Period Precipitation & RPR & 100,2 & 44,16 & 0,355 \\
\hline Number of Growing Season Rain & GSRD & 82,4 & 9,88 & 0,093 \\
\hline
\end{tabular}

An increasing, statistical significant trend is characteristic for many temperature indices. There is no statistical trend as regard precipitation indices

Table 6. Extreme indices for viticulture in Târgu Mureş (period 1951-2017) Significant values are shown in bold (at confidence levels: $* * *=0.001, * *=0.01, *=0.05,+=0.10$ )

\begin{tabular}{|c|c|c|c|c|}
\hline Extreme Index & & Mean & Standard Deviation & $\begin{array}{l}\text { Linear trend } \\
\text { (Mann-Kendall } \\
\text { test, Sen's slope } \\
\text { estimate) }\end{array}$ \\
\hline $\begin{array}{c}\text { Number of Extremely } \\
\text { Hot Days }\end{array}$ & NEHD & 1,0 & 2,84 & \\
\hline Number of Hot Days & NHD & 18,0 & 12,22 & $0.310 * * *$ \\
\hline $\begin{array}{c}\text { Number of Summer } \\
\text { Days }\end{array}$ & NSD & 74,6 & 17,79 & $0.429 * * *$ \\
\hline Number of Frost Days & NFD & 115,0 & 15,36 & $-0.180+$ \\
\hline Number of Icy Days & NID & 21,3 & 12,61 & $-0.136+$ \\
\hline Vitis Frost Risk Days & F8D & 29,1 & 14,48 & $-0,152$ \\
\hline $\begin{array}{c}\text { Vitis Serious Frost Risk } \\
\text { Days }\end{array}$ & FS15D & 9,2 & 8,24 & $-0.080 *$ \\
\hline $\begin{array}{c}\text { Number of Spring Frost } \\
\text { Days }\end{array}$ & NSFD & 21,0 & 6,95 & $-0.087 *$ \\
\hline $\begin{array}{c}\text { Number of Fall Frost } \\
\text { Days }\end{array}$ & NFFD & 20,5 & 7,25 & 0.000 \\
\hline $\begin{array}{l}\text { Spring Frost Index } \\
\text { (Gladstones) }\end{array}$ & $\mathrm{SFI}_{\mathrm{Glad}}$ & 12,5 & 1,77 & 0.0140 \\
\hline $\begin{array}{l}\text { Spring Frost Index } \\
\text { (Wolf and Bayer) }\end{array}$ & $\mathrm{SFI}_{\mathrm{WB}}$ & 6,2 & 0,74 & $0.011 *$ \\
\hline Diurnal Range (July) & DRjul & 22,6 & 2,45 & 0.024 \\
\hline Mean April Daily Range & MADR & 12,4 & 1,47 & 0.021 * \\
\hline $\begin{array}{l}\text { Mean harvest Daily } \\
\text { Range }\end{array}$ & MHDR & 13,2 & 1,39 & 0.004 \\
\hline $\begin{array}{c}\text { Sun of Daily } \\
\text { Temperature Excursion }\end{array}$ & ET & 1979,9 & 155,71 & 1.470 \\
\hline $\begin{array}{l}\text { Ribérau-Gayon-Peynaud } \\
\text { Index }\end{array}$ & RGP & 1052,7 & 149,96 & $3.698 * * *$ \\
\hline
\end{tabular}


Based on Huglin index, Tîrgu Mureș may be included in the second class (cool) (Tonietto and Carbonneau, 2004). Based on Winkler index, Tîrgu Mureș may be included in the first region (very cool) (Winkler et al., 1974).

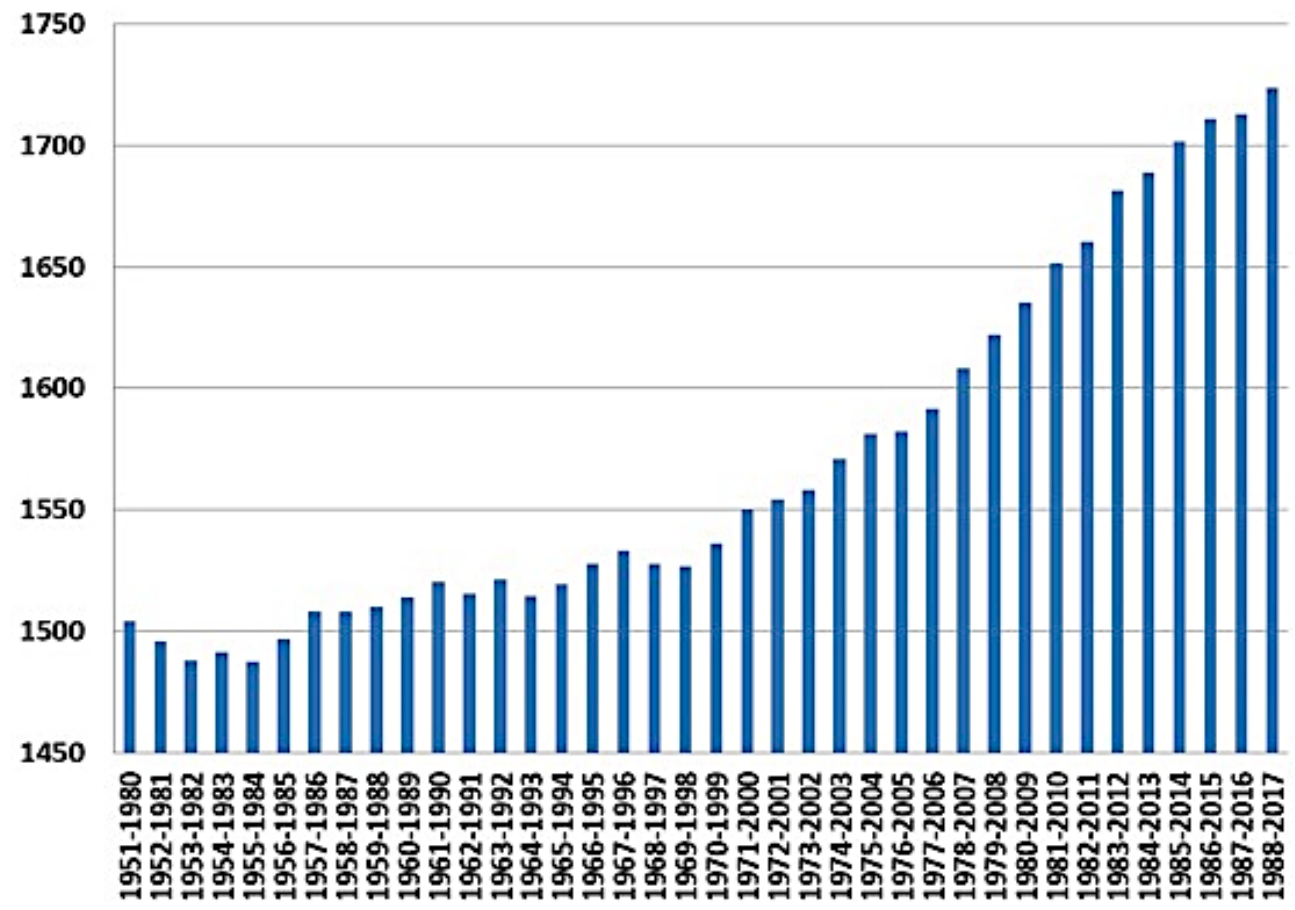

Fig. 8. Huglin index, 30 years overlapped periods for Târgu Mureş (period 1951-2017)

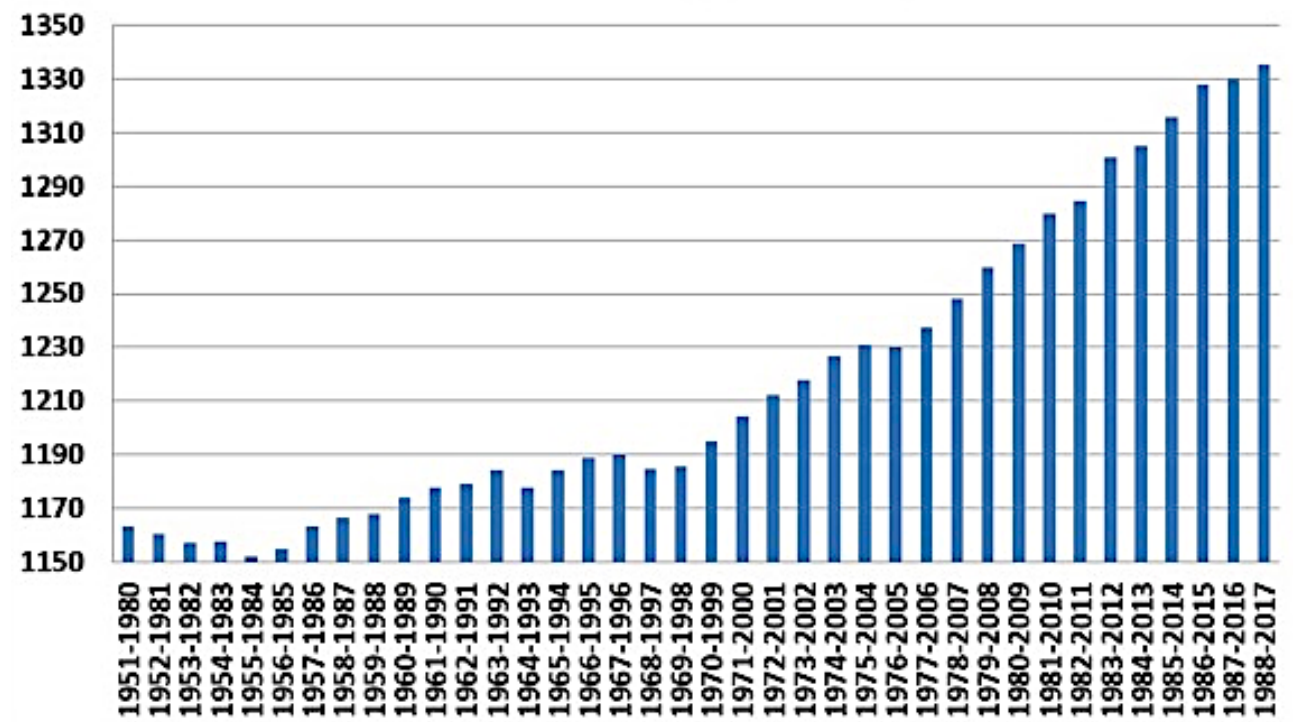

Fig. 9. Winkler index, 30 years overlapped periods for Târgu Mureş (period 1951-2017) 
If the trend of Winkler index will remain, then in the next 1-2 decades this index will rich 1390 (II. Cool). GSAT, GSATX, GSATN determines the dynamics of phenological phases in the reproductive life cycle of the plant. The decreasing, statistical significant trend of FS15D may have a positive effect in viticulture

Overlapped time periods for Huglin-index and Winkler-index are presented in Fig. 8-9. While in the first 30 years periods Huglin index was below 1500 (very cool), in the recent periods this value reached and exceeded 1700 .

\section{CONCLUSIONS}

Tîrgu Mureș is not known from viticulture. However, climate change (especially warming tendencies) may induce some favorable conditions in that direction. Climate change not means only positive effect on viticulture, may be induces some negative effects, e.g increasing of extreme events. Generally, facts of climate change are: warming trend, change in precipitation (amount and distribution), extreme events become more frequent.

The signs of climate change in Tîrgu Mureș are: warming trend (statistically significant positive trend for mean annual and summer temperatures), but actually no change in precipitations or in frequency of extreme events. There are many indices for viticulture.

An increasing, statistical significant trend is characteristic for many temperature indices. There is no statistical significant trend regarding the precipitation indices. Based on Huglin index (HI), Tîrgu Mureș may be included in the second class (cool), and based on Winkler index (WI) may be included in the first region (very cool). Sen's slope estimate for these two indices are 5.417 (for HI) respectively 4.300 (for WI).

If the trend of Winkler index will remain the same, as in the next 1-2 decades, this index will reach 1390 (region II.: cool). Not only the southern exposure, but temperature inversion may have an importance in grape growing.

It may be useful in the future to place weather station in the slopes precisely for viticulture.

\section{REFERENCES}

1. Berbecel, O., Stancu, M., (coord.) (1970), Agrometeorologie. Editura Ceres, Bucuresti, 294. pag.

2. Bognár, K, Mercz, Á. (1995), Szőlöművelés, borkészités. Mezőgazda Kiadó, Budapest, 233 pag.

3. Csete L, Nyéki J. (szerk.) (2006), Klímaváltozás és a magyarországi kertgazdaság. AGRO-21 Kutatási Programiroda, Budapest, 260 pag.

4. Fraga a., malheiro A.C., Moutinho-Pereira J., Santos J.A. (2012), An overwiev of climate change impacts on European viticulture. Food and Energy Security, 1(2), pp. 94-110. DOI: $10.1002 /$ fes 3.14 
5. Hlaszny, E. (2012), A szölö (Vitis vinifera l.) korai fenológiai válaszadásának modellezése a kunsági borvidéken növényfelvételezések, időjárási megfigyelések és regionális klímamodell alapján. Doktori értekezés, Budapesti Corvinus Egyetem, Kertészettudományi Doktori Iskola.

6. Irimia, L. M., Patriche, C.V., Roșca, B. (2017), Changes in oenoclimate aptitude index characterizing climate suitability of romanian wine growing regions. Applied Ecology and Environmental Research, 15(4), pag. 755-767. DOI: http://dx.doi.org/10.15666/aeer/1504_755767

7. Jones, G. (2007), Climate change: Observations, projections, and general implications for viticulture and wine production. Climate and Viticulture Congress, Zaragoza, April.

8. Kendall, M.G. (1975), Rank correlation method, 4th Ed., Charles Griffin, Londres.

9. Mann, H.B. (1945), Non-parametric test against trend. Econometrica, 13, pp. 245-249

10. Nesbitt, A., Kemp, B., Steele, C., Lovett, A., Dorling, S., (2016), Impact of recent climate change and weather variability of UK viticulture- combining weather and climate records with producers' perspectives. Australian Journal of Grape and Wine Research 22, pp. 324-335. DOI: 10.1111/ajgw.12215

11. Rusz, O. (2015), Temperature inversions in Transylvania. Air and Water Components of the Environment, Cluj-Napoca, pp 385-395.

12. Rusz, O. (2019), Some characteristics of precipitation in the central region of Romania in the 1961-2017 period. Air and Water Components of the Environment, Cluj-Napoca, pp 385-395, pp 299-309.

13. Salmi, T., Määttä, A., Anttila, P., Ruoho-Airola, T., Amnell T. (2002) Makesens 1.0

14. Tonietto, J., Carbonneau, A. (2004): A multicriteria climatic classification system for grape-growing regions worlwide. Agricultural and Forest Meteorology, Amsterdam, v.124, p.81-97.

15. Winkler, A. J., Cook, J. A., Kliere, W. M., Lider, L. A. (1974), General Viticulture (2nd ed.). University of California Press.

16. ***(1888), Borászati Lapok, 36/20, pp. 308

17. ***(1896), Borászati Lapok, 28/36, pp. 1

18. ***Curs de instruire profesională pentru responsabilii cu activitatea de măsurători și observații agrometeorologice din rețea (2004). Intern material National Meteorological Administration, Bucuresti

19. ***Meteorological tabels from Tîrgu Mureș (1951-2017) 
